\title{
Game Therapy Studies: A Review and Meta-Analysis Sample
}

\author{
Suna TARKOÇİN VURAL* \\ Childcare and youth services division, Bingol University, Bingol, Turkey \\ ORCID: 0000-0002-3380-2144
}

\begin{tabular}{l}
\hline \hline Article history \\
\hline Received: \\
16.12 .2020
\end{tabular}

Received in revised form: 03.12.2021

Accepted:

10.01.2022

Key words: play therapy; meta-analysis; child

\section{Mehmet SAĞLAM \\ Child Development, Inonu University, Malatya, Turkey \\ ORCID:0000-0003-1784-4472}

Gaming is a natural process for the child, and with the play therapy technique used in this process, opportunities are offered to the child to express their problems and emotions by playing. Play therapy is used in many studies with children. The number of studies conducted on the effectiveness of play therapy in Turkey is increasing with each passing day. In this study, experimental graduate studies related to the play therapy education program from the past to the present (1987-2020) were examined and the results were brought together. A total number of 38 master's and 8 doctoral studies were reached in the YÖK (Council of Higher Education) thesis center related to the subject, but only 7 studies in accordance with the inclusion criteria were analyzed with metaanalysis method. While examining the postgraduate studies, care was taken toward the existence of an experimental and control group in which play therapy was applied. The studies in which play therapy was applied to the experimental group but not the control group were included in this study. In order to calculate the effect sizes, average (X), standard deviation (SS) and sample size (N) values from master's theses were processed in the Excel program. Later, CMA (Comprehensive Meta Analysis) statistical program was used for the analysis required for the study, "Hedges's g" was used to calculate the effect size and the Excel program was used for the collection-processing of the data. As a result of the research, it was found that the effect size of play therapy on children's behaviors has an excellent effect size. It was concluded that 5 of the studies included in the study were excellently effective, 1 was moderately effective, and 1 was broadly effective. These limited studies provide information that play therapy has a positive effect on children.

\section{Introduction}

Play is a natural process for children. When the literature was examined, it was seen that the play was defined in different ways. When defining the play, Turkish Language Association (2020) defines the play as an entertainment that improves talent and intelligence, 
has certain rules, and helps to have a good time. Yavuzer (2005), on the other hand, defined the play as an activity that is done for having fun without thinking about the results. Play is a liberating action that gives children pleasure by distracting them from their daily worries, while at the same time allowing them to overcome their daily worries by bringing them into their play. Play is generally expressed as fun activities that start after the birth of the child and last for a lifetime, and which can be done sometimes purposefully and sometimes without purpose (Halmatov, 2018; Karsl1, 2016; Öğretir, 2008; Sezen Dursun, 2018; Whitebread, 2012).

Play, which is of great importance in a child's life, is one of the most important and reliable ways to understand and get to know a child. Because the child is in purest state during play. Plato drew attention to the fact that one hour of participating in a child's plays is enough to get to know and understand a child rather than being with him/her for years and the power of the play. The play has many effects on the child. Especially the healer, instructive and developer aspects make the game powerful. Although play is a good tool that reflects the inner world of the child, it also plays an effective role in the child's gaining insight. The contribution of the game to the development of mental status, metacognitive skills, healthy mood, language skills, representation and self-regulation skills comes to the forefront in many studies, and the game allows the child to use their creativity. Ögrretir (2008) stated that the play is a natural tool for the child, and it is a tool that contributes to the development of the child's social and cognitive skills. While playing contributes to a good childhood and development of the child, it also helps to increase the child's motivation for learning. Play is an important tool that contributes to a child's physical, emotional, and mental well-being. When children play; they gain experience about life skills, problem-solving skills, communication skills, social skills, thinking skills, research skills, and self-direction and self-administration (Önder, 2018; Sutton-Smith, 2008; Tuğrul, 2019; VanFleet et al, 2020, p.35). Play for children is what verbal expressions are to adults. Play is the most natural way of expressing oneself and also the language of the child. The game allows the child to speak to us without words (Kaduson, 2019 , p.11). Research about play is important in understanding the child's experiences and creating suitable environments for the child's development. It is important for parents and individuals working with children to have knowledge about play and play therapy in terms of establishing constructive communication with the child and realizing that play is a door to the child's inner world (Öğretir, 2008).

Many experts use play therapy as a method in order to recognize many problems that occur in children and to help children overcome them. VanFleet et al. (2020), stated that play enables children to reveal their experiences and provides relief in the emotional field and that it is understandable to use it in therapy. They also stated that play itself is also a therapy. Play therapy was first proposed by child psychotherapists Anna Freud, Margaret Lowenfeld, and Melanie Klein. When the studies are examined; it is seen that play therapy studies have become more prominent in recent years although there is not much history of play therapy in our country. The Play Therapy Association defines play therapy as "a powerful therapy method that helps children express their emotions and cope with their mental problems, as well as change their maladaptive behaviors, develop their self-esteem and establish healthy relationships". Wilson and Ryan (2005) stated that play is the process of creating intense relationship experiences between the therapist and the child, and play therapy is a communication tool in this process. When the literature is examined, it is seen that there are many types of play therapy. These include psycho-analytical play therapy, cognitive behavioral play therapy, developmental play therapy, child-centered play therapy, filial play therapy, gestalt play therapy, theraplay, jungcu play therapy, Ericksonian play therapy, 
Adlerist play therapy. Play therapy should be planned in accordance with the development and characteristics of each child and should be selected from the types of play therapy (British Association of Play Therapists, 2020; Deniz, 2019; Koç and Yumru, 2019; Temizel, 2019). VanFleet and Faa-Thompson (2010) stated that one of the advantages of play therapy is that it does not require language or verbal expression in children because they stated that this activates the natural tendency of children to play, that children express themselves, communicate and solve problems more readily than the speech-oriented and more cognitive methods designed for adults.

There are many studies in the literature that show that play therapy has a positive effect on children's behavior. In a study of Schottelkorb et al. (2020), It was concluded that childcentered play therapy has a therapeutic effect on the social sensitivity, externalization problems, attention problems and aggression of children with autism. In a study of Uysal (2020); it was concluded that Theraplay play therapy has a healing effect on the emotional and behavioral problems of Syrian refugee children. Ahbab (2019) concluded that play therapy has a healing effect on children's anger problems. In a study of Blanco et al. (2019), titled as the effect of child-centered play therapy on the academic success of at-risk kindergarten students, concluded that child-centered play therapy has a positive effect on academic achievement. In the study of Ray et al. (2009), it was concluded that child-centered play therapy has a curative effect on the behaviors of children with aggressive behavior. In their study, Kilınç and Saltık (2018) concluded that the problematic behaviors previously seen in children participating in play therapy decreased after the therapy. Kockaya and Siyez (2017) concluded in their research that play therapy has a significant effect on children's shyness behaviors. Montemayor (2014) concluded that child-centered play therapy positively affects children with behavioral problems in the preschool period. Chinekesh et al. (2013), concluded that play therapy has a positive effect on improving the social-emotional skills of children. Looking at the results of the relevant research, it is seen that play therapy is effective on children's emotional and behavioral problems, social skills, and developmental problems. In this study, the effect size of play therapy was tried to be calculated in thesis studies on play therapy and an answer was sought for the following question:

- What is the effect size of play therapy on dependent variables?

\section{Method}

\section{Literature Review}

Research data include graduate thesis about play therapy in Turkey. Sample selection was made with purposeful sampling method. Purposeful sampling is to conduct in-depth research by selecting information-rich situations depending on the purpose of the research. Purposeful sampling is a preferred sampling method when it is desired to work in one or more special situations that meet certain criteria or have certain characteristics (Koç Basaran, 2017). During the research, the words "oyun terapisi" in Turkish and "playtherapy" in English were used as key words on the YÖK (Higher Education Council) thesis page. A total of 46 studies from 1987 to 2020 were determined as a result of the screening. However, 7 studies that met the inclusion criteria were included in this meta-analysis study. 


\section{Inclusion criteria}

The aim of this study is to identify postgraduate studies on play therapy that have been made in Turkey and reveal the general profile of these studies. It is aimed that all of the studies examined in this study are directed to play therapy. In a meta-analysis study, it is important to formulate the inclusion criteria for the respective studies. If inclusion criteria is kept very broad, the quality of the studies included may get weaken which would ultimately reduce the reliability of the output. If the inclusion criteria are kept strict, the results may be based on limited number of studies and generalisation would be more difficult (Lam and Kenedy, 2005). In this study, following criteria applied to avoid above two scenarios:

- Access to postgraduate theses in full text in YÖK (Higher Education Council) thesis database,

- Including numerical data that will enable the calculation of the effect sizes of the studies,

- The scales used in the studies contain total score data other than sub-dimensions,

- The language of the studies is Turkish or English,

- Studies containing the following keywords "oyun terapi" and "play therapy",

- The studies were conducted with children between the ages of 0-18,

In the meta-analysis study, the effect size of 7 studies that met these criteria was calculated.

\section{Including Sufficient quantitative Data}

In order to calculate effect sizes in meta-analysis studies, quantitative data are needed for the experimental and control groups of the studies (Göçmen, 2004). For this purpose, studies with sample size $(\mathrm{N})$, mean $(\mathrm{X})$, standard deviation $(\mathrm{SD})$ values of the experimental and control groups were included in the meta-analysis study.

\section{Coding}

The purpose of this study is to reveal a general review about postgraduate studies on play therapy and to obtain data on the effectiveness levels of play therapy education / program used in these postgraduate studies. First of all, demographic information, effect size calculations and qualitative summaries of the examined postgraduate theses were carried out in the study. The coding method used in the study was collected under 2 headings. The first part includes the demographic characteristics of the research (author names, the year of the study, the institute / department where the study was conducted, the language of the study, dependent and independent variables, the result of the research). In the second part, sample size $(\mathrm{N})$, mean $(\mathrm{X})$ and standard deviation (SS) obtained from experimental and control groups were included in order to calculate the effect size. Expert opinion was sought during the coding stage of this study and following that the necessary analyses has been performed.

\section{Effect Size Calculation}

Effect size forms the basis of the meta-analysis and expresses the incidence of the phenomenon (Kural, 2020). For effect size values based on arithmetic averages, effect sizes are grouped in six groups as insignificant, small, medium, large, very broad and excellent.

In this study, $\mathrm{X}, \mathrm{SS}$ and $\mathrm{N}$ values from theses were processed in Excel program to calculate the effect sizes. Then, CMA (Comprehensive Meta Analysis) statistics program was used for 
the analysis required for the study. "Hedges's g" was used in the calculation of the effect size and Excel 2010 programs were used in the collection-processing of data. Results are given in Table 4.

\section{Heterogeneity Test and Meta-Analysis Model Application}

It is crucial to evaluate heterogeneity in meta-analysis study. Output of the heterogeneity test is very important as it is being used to determine the model for general impact calculation. If the $\mathrm{p}$ value is less than 0,05 or $\mathrm{Q}$ value is greater than the value corresponding to the df value in the chi-square table, it can be concluded that meta-analysis application has a heterogenous structure following the inclusion of the individual studies. That is, these studies are not of a similar nature. In this circumstance, the analysis should be performed under the random effects model (Dincer, 2004). In this study, heterogeneity analysis has been performed to determine which meta-analysis model to be used for the interpretation of study impact.

Table. 1 Heterogeneity Analysis

\begin{tabular}{|c|c|c|c|c|c|c|c|c|c|c|c|c|}
\hline \multirow{2}{*}{ Model } & \multicolumn{6}{|c|}{ Impact size and $\% 95$ confidence interval } & \multicolumn{2}{|c|}{$\begin{array}{l}\text { Test of null(2- } \\
\text { Tail) }\end{array}$} & \multicolumn{4}{|c|}{ Heterogeneity } \\
\hline & $\begin{array}{l}\text { Number } \\
\text { Studies }\end{array}$ & $\begin{array}{l}\text { Point } \\
\text { estimate }\end{array}$ & $\begin{array}{l}\text { Standard } \\
\text { error }\end{array}$ & Variance & $\begin{array}{l}\text { Lower } \\
\text { limit }\end{array}$ & $\begin{array}{l}\text { Upper } \\
\text { limit }\end{array}$ & $\begin{array}{l}\mathrm{Z}- \\
\text { value }\end{array}$ & $\begin{array}{l}\mathrm{P}- \\
\text { value }\end{array}$ & $\begin{array}{l}\text { Q- } \\
\text { value }\end{array}$ & $\begin{array}{l}\mathrm{df} \\
(\mathrm{Q})\end{array}$ & P-value & I-squared \\
\hline Fixed & 7 & 1,242 & 0,148 & 0,022 & 0,952 & 1,531 & 8,405 & 0,000 & 22,579 & 6 & 0,001 & 73,426 \\
\hline Random & 7 & 1,558 & 0,322 & 0,104 & 0,927 & 2,189 & 4,838 & 0,000 & & & & \\
\hline
\end{tabular}

Table 1 shows $\mathrm{p}<0,05(\mathrm{p}=0,001)$ which implies significant difference between the groups. Since study suggests heterogenous structure overall impact should be considered under the Random Impact Model.

\section{Interpretation of Effect Size}

The effect sizes obtained as a result of the meta-analysis can be interpreted according to the coefficient classification. "Hedge's g" was used in calculating the effect size in this study. The following classification was used to interpret the effect sizes in the study (Thalheimer and Cook, 2002):

- $-0.15-0.15$ insignificant

- $0.15-0.40$ low

- $0.40-0.75$ moderate

- $0.75-1.10$ broad

- $1.10-1.45$ very broad

- 1.45 - excellent

\section{Results}

46 studies were compiled as a result of the scanning. The number of those who met the selection criteria among these studies was limited to 7 . While screening, care was taken to for the presence of an experiment and control group in which play therapy was applied. This therapy was applied to the experimental group, but not to the control group. It is concluded that play therapy has an effect when the difference between these two groups is significant. The theses used are shown in Table 2. and Table 3. 


\section{Demographic Information}

Table 2. General Summary of the Study

\begin{tabular}{|c|c|c|c|c|c|c|c|c|c|}
\hline Variables & & T1 & T2 & T3 & T4 & T5 & T6 & T7 & TOTAL \\
\hline \multirow[t]{2}{*}{ Thesis Type } & Master's thesis & $\mathrm{X}$ & $\mathrm{X}$ & $\mathrm{X}$ & & $\mathrm{X}$ & & & $57,14 \%$ \\
\hline & Doctorate thesis & & & & $X$ & & $\mathrm{X}$ & $X$ & $42,86 \%$ \\
\hline \multirow{2}{*}{$\begin{array}{l}\text { Year of the } \\
\text { Thesis }\end{array}$} & $2011-2015$ & & & & $\mathrm{X}$ & & & $\mathrm{X}$ & $28,57 \%$ \\
\hline & 2016-2020 & $\mathrm{X}$ & $\mathrm{X}$ & $\mathrm{X}$ & & $\mathrm{X}$ & $\mathrm{X}$ & & $71,43 \%$ \\
\hline \multirow{2}{*}{$\begin{array}{l}\text { Language of } \\
\text { the Thesis }\end{array}$} & Turkish & $\mathrm{X}$ & $\mathrm{X}$ & $\mathrm{X}$ & $\mathrm{X}$ & $\mathrm{X}$ & & $\mathrm{X}$ & $85,71 \%$ \\
\hline & English & & & & & & $X$ & & $14,29 \%$ \\
\hline \multirow[t]{2}{*}{ Institute } & Institute of Social Sciences & $\mathrm{X}$ & $\mathrm{X}$ & & & $\mathrm{X}$ & & & $42,86 \%$ \\
\hline & Health Sciences Institute & & & $\mathrm{X}$ & $X$ & & $X$ & $X$ & $57,14 \%$ \\
\hline \multirow[t]{7}{*}{ Department } & Psychology Department & & $\mathrm{X}$ & & & $\mathrm{X}$ & & & $28,57 \%$ \\
\hline & Clinical Psychology Department & $\mathrm{X}$ & & & & & & & $14,29 \%$ \\
\hline & Child Health and Disease Nursing & & & & $\mathrm{X}$ & & & $\mathrm{X}$ & $28,57 \%$ \\
\hline & Physical Education and Sports & & & & & & $X$ & & \\
\hline & Department & & & & & & & & $14,29 \%$ \\
\hline & Child Development and Education & & & $\mathrm{X}$ & & & & & \\
\hline & Department & & & & & & & & $14,29 \%$ \\
\hline \multirow{2}{*}{$\begin{array}{l}\text { Sample } \\
\text { Group }\end{array}$} & $0-18$ years old children & $\mathrm{X}$ & & $\mathrm{X}$ & $\mathrm{X}$ & & & $\mathrm{X}$ & $57,14 \%$ \\
\hline & Disabled children & & $\mathrm{X}$ & & & $\mathrm{X}$ & $\mathrm{X}$ & & $42,86 \%$ \\
\hline \multirow{2}{*}{$\begin{array}{l}\text { Model of the } \\
\text { Thesis }\end{array}$} & Experimental & & $\mathrm{X}$ & $\mathrm{X}$ & $\mathrm{X}$ & $\mathrm{X}$ & $\mathrm{X}$ & $\mathrm{X}$ & $85,71 \%$ \\
\hline & Semi Experimental & $\mathrm{X}$ & & & & & & & $14,29 \%$ \\
\hline $\begin{array}{l}\text { Method of the } \\
\text { Thesis }\end{array}$ & Qualitative & $\mathrm{X}$ & $\mathrm{X}$ & $\mathrm{X}$ & $\mathrm{X}$ & $\mathrm{X}$ & $\mathrm{X}$ & $\mathrm{X}$ & $100,00 \%$ \\
\hline \multirow{9}{*}{$\begin{array}{l}\text { The type of } \\
\text { problem } \\
\text { being studied } \\
\text { in } \\
\text { conjunction } \\
\text { with Play } \\
\text { Therapy }\end{array}$} & Behavior problems / disorders & & & $\mathrm{X}$ & & & & & $10,00 \%$ \\
\hline & Behavior Management & & & & $X$ & & & & $10,00 \%$ \\
\hline & Anxiety / Separation Anxiety / Social & & $\mathrm{X}$ & & & & & & \\
\hline & Anxiety & & & & & & & & $10,00 \%$ \\
\hline & Social Skill & & & $\mathrm{X}$ & & $X$ & & & $20,00 \%$ \\
\hline & $\begin{array}{l}\text { Social cohesion and emotion } \\
\text { regulation }\end{array}$ & & & & $X$ & & & $X$ & $20,00 \%$ \\
\hline & Anger Problem & $\mathrm{X}$ & & & & & & & $10,00 \%$ \\
\hline & Family attitudes and academic success & & $\mathrm{X}$ & & & & & & $10,00 \%$ \\
\hline & $\begin{array}{l}\text { Motor function, balance, functional } \\
\text { independence, physical fitness }\end{array}$ & & & & & & $\mathrm{X}$ & & $10,00 \%$ \\
\hline \multirow{3}{*}{$\begin{array}{l}\text { Play Therapy } \\
\text { Type }\end{array}$} & Child-centered play therapy & & $\mathrm{X}$ & & & & & & $14,29 \%$ \\
\hline & Play Therapy & $\mathrm{X}$ & & $\mathrm{X}$ & $\mathrm{X}$ & & $\mathrm{X}$ & $\mathrm{X}$ & $71,43 \%$ \\
\hline & Developmental Play Therapy & & & & & $X$ & & & $14,29 \%$ \\
\hline
\end{tabular}

A total of 46 studies were found as a result of the searching process conducted at the YÖK thesis center. The number of studies meeting the inclusion criteria in these studies was limited to 7 . It is seen that $57.14 \%$ of the studies are master's thesis and $42.86 \%$ are doctoral thesis. In the studies, it is seen that $57.14 \%$ of the sample groups are children in the $0-18$ age group, while $42.86 \%$ are disabled individuals. It is seen that $28.57 \%$ of the studies were conducted between 2011-2015 and 71.43\% between 2015-2020. It is seen that $85.71 \%$ of the studies are experimental and $14.29 \%$ are semi-experimental. It is seen that $42.86 \%$ of the studies were worked in the Institute of Social Sciences and 57.24\% in the Institute of Health Sciences. It is seen that most of the studies were studied in the Department of Psychology and the Department of Child Health and Disease Nursing (28.57\%). It is seen that all of the studies are qualitative and $85.71 \%$ of them are published in Turkish. It is seen that $20 \%$ of the emotional / behavioral problem types examined together with play therapy in studies are social skills, social adaptation, and emotion regulation. Other types of problems are seen to be 
behavioral problem / disorder, behavior management, anxiety, anger problem, family attitudes and academic achievement, motor function, balance, functional independence, physical fitness. Among the types of play therapy in the studies; it is seen that only play therapy is used with a ratio of $71.43 \%$, child-centered play therapy with a ratio of $14.29 \%$ and developmental play therapy with a ratio of $14.29 \%$.

Table 3. General Summary of Studies

\begin{tabular}{|c|c|c|c|c|c|c|}
\hline Year & Author & $\begin{array}{l}\text { Independent } \\
\text { variable }\end{array}$ & $\begin{array}{l}\text { Dependent } \\
\text { variable }\end{array}$ & $\begin{array}{l}\text { Sample } \\
\text { Group }\end{array}$ & Tool & Result \\
\hline 2019 & $\begin{array}{l}\text { Afra } \\
\text { Ahbab }\end{array}$ & Game Therapy & $\begin{array}{l}\text { Anger } \\
\text { problem }\end{array}$ & $\begin{array}{l}50 \text { children } \\
\text { aged } \\
\text { between 5- } \\
12 \text { years }\end{array}$ & $\begin{array}{l}\text { State-Trait } \\
\text { Anger } \\
\text { Expression } \\
\text { Inventory } \\
\text { (STAXI) }\end{array}$ & $\begin{array}{l}\text { The results showed } \\
\text { significant } \\
\text { improvements in anger } \\
\text { problem measures based } \\
\text { on both self-report and } \\
\text { parental reporting in the } \\
\text { therapy group. }\end{array}$ \\
\hline 2019 & $\begin{array}{l}\text { Gülşah } \\
\text { Aydın } \\
\text { Yeşilyurt }\end{array}$ & $\begin{array}{l}\text { Child- } \\
\text { Centered Play } \\
\text { Therapy }\end{array}$ & $\begin{array}{l}\text { Immediate, } \\
\text { continuous } \\
\text { and social } \\
\text { anxiety, } \\
\text { perceived } \\
\text { parental } \\
\text { attitudes, } \\
\text { academic } \\
\text { achievements } \\
\text { and cognitive } \\
\text { assessment } \\
\text { systems }\end{array}$ & $\begin{array}{l}14 \text { children } \\
\text { diagnosed } \\
\text { with } \\
\text { special } \\
\text { learning } \\
\text { difficulties, } \\
\text { their } \\
\text { families, } \\
\text { and } \\
\text { teachers }\end{array}$ & $\begin{array}{l}\text { Social } \\
\text { Anxiety } \\
\text { Scale for } \\
\text { Children- } \\
\text { Revised, The } \\
\text { Instant-Trait } \\
\text { Anxiety } \\
\text { Inventory for } \\
\text { Children } \\
\text { (STAI-CH), } \\
\text { Cognitive } \\
\text { Assessment } \\
\text { System, } \\
\text { Parent } \\
\text { Attitude } \\
\text { Scale }\end{array}$ & $\begin{array}{l}\text { Child-centered play } \\
\text { therapy was found to be } \\
\text { effective on anxiety } \\
\text { levels, attention, and } \\
\text { planning skills, and not } \\
\text { on perceived family } \\
\text { attitudes and academic } \\
\text { success in children with } \\
\text { specific learning } \\
\text { difficulties. }\end{array}$ \\
\hline 2018 & Nalan Saltık & $\begin{array}{l}\text { Game(play) } \\
\text { Therapy }\end{array}$ & $\begin{array}{l}\text { Social skills } \\
\text { and problem } \\
\text { behaviors }\end{array}$ & $\begin{array}{l}8 \text { children } \\
\text { aged } \\
\text { between 3- } \\
6 \text { years }\end{array}$ & $\begin{array}{l}\text { Preschool } \\
\text { and } \\
\text { Kindergarten } \\
\text { Behavior } \\
\text { Scale } \\
\text { (PKBS-2), } \\
\text { Social Skills } \\
\text { Scale }\end{array}$ & $\begin{array}{l}\text { Play therapy has been } \\
\text { found to be effective on } \\
\text { social skills and } \\
\text { problem behaviors of } \\
\text { children aged between } \\
\text { 3-6 years. }\end{array}$ \\
\hline 2018 & $\begin{array}{l}\text { Gülden } \\
\text { Öztürk } \\
\text { Serter }\end{array}$ & $\begin{array}{l}\text { Psycho- } \\
\text { Education } \\
\text { Program } \\
\text { Based on } \\
\text { Structured } \\
\text { Play Therapy }\end{array}$ & $\begin{array}{l}\text { Children's } \\
\text { compliance } \\
\text { with divorce } \\
\text { and } \\
\text { depression } \\
\text { levels }\end{array}$ & $\begin{array}{l}16 \text { children } \\
\text { aged } \\
\text { between 9- } \\
12 \text { years }\end{array}$ & $\begin{array}{l}\text { Divorce } \\
\text { Adjustment } \\
\text { Scale for } \\
\text { Children, } \\
\text { Depression } \\
\text { Scale for } \\
\text { Children }\end{array}$ & $\begin{array}{l}\text { It was concluded that } \\
\text { the psychoeducational } \\
\text { program developed } \\
\text { based on structured play } \\
\text { therapy was effective in } \\
\text { increasing the level of } \\
\text { divorce adjustment of } \\
\text { 9-12-year-old children } \\
\text { whose parents divorced } \\
\text { and also reduced their } \\
\text { depression levels. }\end{array}$ \\
\hline 2017 & Ayşe Bayam & $\begin{array}{l}\text { Developmental } \\
\text { Play Therapy }\end{array}$ & $\begin{array}{l}\text { Social Skills } \\
\text { and } \\
\text { Language } \\
\text { Development }\end{array}$ & $\begin{array}{l}35 \text { children } \\
\text { aged } \\
\text { between } \\
2-6 \text { years }\end{array}$ & $\begin{array}{l}\text { Ankara } \\
\text { Development } \\
\text { Screening } \\
\text { Inventory } \\
\text { (AGTE) }\end{array}$ & $\begin{array}{l}\text { It has been concluded } \\
\text { that children with } \\
\text { autistic spectrum } \\
\text { disorder between the } \\
\text { ages of } 2 \text { and } 6 \text { have an } \\
\text { increase in their } \\
\text { language development }\end{array}$ \\
\hline
\end{tabular}


and social skill levels as

they receive play

sessions.

Gross Motor

Function

Measurement As a result, it is thought

19 children (GMFM) that the play-based

Physical aged Measuring

therapy and between 6- Functional

rehabilitation

programs motor activity program can be used in addition to physical therapy and rehabilitation programs
10 years Independence

diagnosed Skills

with $\mathrm{CP}$

(WeeFIM)
Presidential

Physical

Fitness Test

Preschool

Child and

Social, emotional, behavioral

2013 Emel Sezici Play Therapy

Family skills in between 4-

preschool

children

5 years
Identification

Form, Social

Competence

and Behavior

Evaluation

Scale in children with cerebral palsy.

The general summary of the master's theses examined within the scope of the research is given in Table 3 above.

Table 4. Effect Size Calculations

\begin{tabular}{|c|c|c|c|c|c|}
\hline Number & Group & $\mathrm{N}$ & $\underline{X}$ & SS & Hedges's g \\
\hline \multirow{2}{*}{1.} & Experimental & 25 & 13.40 & 2.16 & 1.735 \\
\hline & Control & 25 & 10.52 & 0.82 & \\
\hline \multirow{2}{*}{2.} & Experimental & 7 & 79.71 & 10.30 & 0.785 \\
\hline & Control & 7 & 73.14 & 4.10 & \\
\hline \multirow{2}{*}{3.} & Experimental & 4 & 91.66 & 7.30 & 1.571 \\
\hline & Control & 4 & 68.50 & 16.6 & \\
\hline \multirow{2}{*}{4.} & Experimental & 8 & 81.63 & 4.03 & 2.373 \\
\hline & Control & 8 & 64.50 & 8.77 & \\
\hline \multirow{2}{*}{5.} & Experimental & 20 & 6.00 & 2.47 & 1.506 \\
\hline & Control & 15 & 2.47 & 2.02 & \\
\hline \multirow{2}{*}{6.} & Experimental & 9 & 112.22 & 3.54 & 3.095 \\
\hline & Control & 10 & 99.70 & 4.13 & \\
\hline \multirow{2}{*}{7.} & Experimental & 39 & 48.948 & 5.78 & 0.600 \\
\hline & Control & 40 & 44.85 & 7.60 & \\
\hline
\end{tabular}


Table 5.Meta Analysis

Meta Analysis

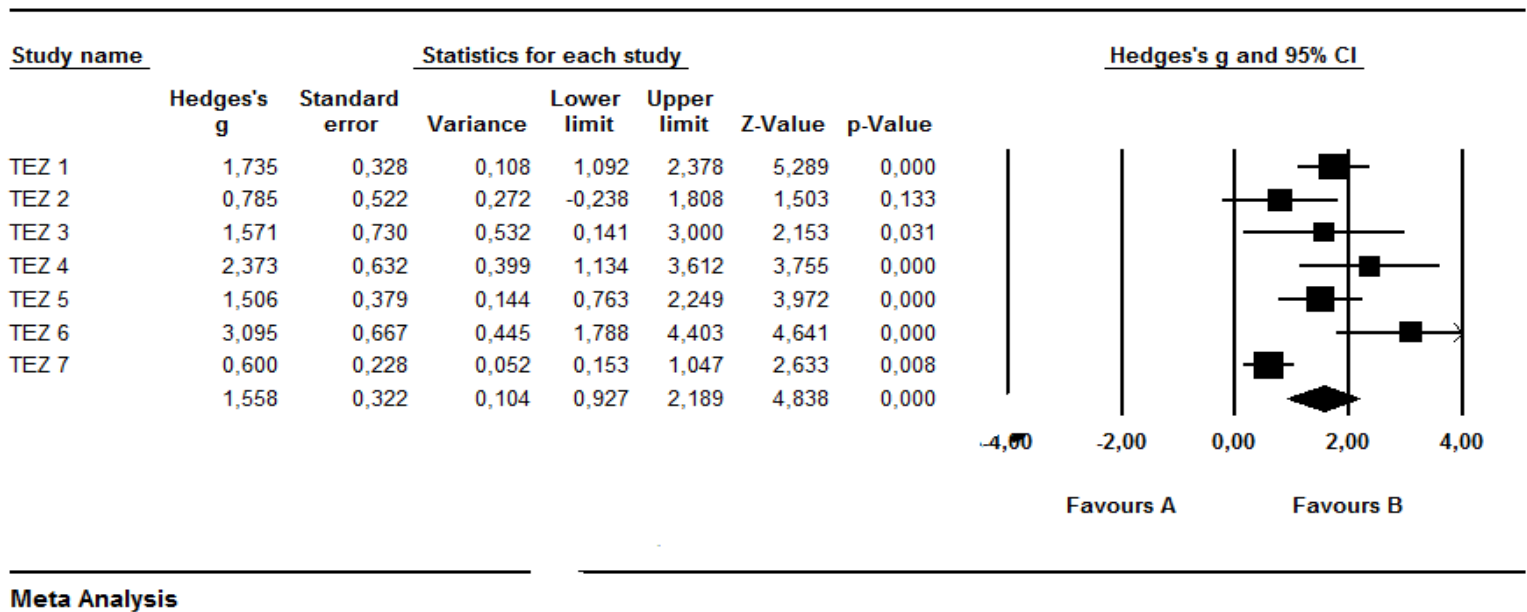

It is aimed to obtain the average of effect size values obtained from each study used in metaanalysis. However, the mean value to be calculated in meta-analysis is not the arithmetic mean value. Since the sample size of each study used in meta-analysis is different, the contribution of each study to the general average is not the same. Weighted average is calculated in meta-analyzes considering the different sample sizes (Şen, 2019). When Table 4 is examined, it is seen that the effect size of play therapy is 1.558 .

Table 6. Classification of Effect Sizes

\begin{tabular}{ll}
\hline Effect Size & F \\
\hline$-0.15-0.15$ Insignificant & 0 \\
$0.15-0.40$ Low & 0 \\
$0.40-0.75$ Moderate & 1 \\
$0.75-1.10$ Broad & 1 \\
$1.10-1.45$ Very Broad & 0 \\
$\geq 1.45-$ Excellent & 5 \\
\hline
\end{tabular}

When Table 6 is examined, it is seen that 5 studies have an excellent effect size, 1 study has a moderate effect size, and 1 study has a broad effect size.

\section{Discussion}

The number of studies conducted on the effectiveness of play therapy in Turkey is increasing every day. In this study, experimental graduate studies on play therapy education and program from the past to the present (1987-2020) were examined and the results were brought together. A total number of 38 master's thesis and 8 doctoral thesis studies were found in the YÖK (Higher Education Council) thesis center related to the subject, but 7 studies in accordance with the inclusion criteria were analyzed by meta-analysis method. As a result of the research, it was found that the effect size of play therapy on children's behaviors was 1.558 at excellent level. It was seen that 5 studies have an excellent effect size, 1 study has a moderate effect size, and 1 study has a broad effect size. These limited number of studies provide information that play therapy has a positive effect on children.

In the research of Blanco and Ray (2011), examining the effectiveness of child-centered play therapy in first year students with academic achievement risk, they stated that play therapy is 
effective in increasing the academic success of children and the results of the research support the use of play therapy as an intervention program in academic success. In a study of Altun et al. (2019), it was concluded that developmental play therapy is effective in reducing posttraumatic stress symptoms of orphans and children in need of protection. In a study of Soniya et al. (2019), in which the effect of play therapy on anxiety was examined in hospitalized preschool children, it was concluded that play therapy is an inexpensive treatment used to reduce anxiety. In a study of Ray et al. (2009), it has been concluded that child-centered play therapy reduces children's aggressive behaviors. Schumann (2010) concluded that childcentered play therapy is effective in reducing children's aggressive behaviors. Swan and Ray (2014), after studying the effect of child-centered play therapy on the hyperactivity and nervousness behaviors of two children with mental disabilities, concluded that child-centered play therapy reduced the hyperactivity and irritability behaviors seen in children and improved their behavior. Hayati et al. (2014), in their study examining the effect of childcentered play therapy on the aggression level of children aged between 5-10 years, concluded that child-centered play therapy is effective in reducing children's aggression levels. As a result of their research, Iswinarti and Hidayah (2020) stated that group play therapy improves children's empathy skills and reduces aggressive behaviors. As a result of the research, it was concluded that play therapy has an excellent effect on children's behavior. When the literature is examined, studies show us that play therapy is effective in reducing aggression behavior, stress symptoms and anxiety seen in children, and also supports the result of our study.

When the literature is examined, meta-analysis studies on play therapy that support the results of the findings obtained within the scope of the study were encountered. In their metaanalysis study, LeBlanc and Ritchie (2001) examined 42 studies conducted between 1947 and 1996 and concluded that play therapy is as effective as non-play therapies in the treatment of children with emotional difficulties and reported the effect size as 0.66. Ray et al. (2015) examined 23 studies conducted between 1975 and 2011 in their meta-analysis study and concluded that school-based play therapy has small and medium statistically significant effect sizes on children's problem behaviors, internalizing and externalizing problem behaviors, selfefficacy, and academic achievement. Lin and Bratton (2015) examined 52 studies conducted between 1995 and 2010 in their meta-analytical study of child-centered play therapy approaches and concluded that the effect size of child-centered play therapy was moderate (0.47). Bratton et al. (2005) examined 93 studies conducted between 1953-2000 in their study on the effectiveness of behavioral play therapy and found the overall effect size as 0.80. Slade and Warne (2016) examined 10 studies that met the inclusion criteria in their meta-analytical study, where they examined the effectiveness of trauma-focused cognitive-behavioral therapy and play therapy to help victims of child abuse. As a result of their research, they concluded that play therapy is beneficial for child abuse victims, but cognitive-behavioral therapy is more effective throughout the study. They also stated that play therapy may be more effective in children with externalized behavioral problems.

\section{Conclusion and Recommendations}

When the results obtained within the scope of the study were examined, it was found that the effectiveness of play therapy studies was high. The results obtained in this metaanalysis study including master's thesis studies about play therapy that were registered in YÖK (Higher Education Council) thesis center in Turkey were found to be compatible with studies which were conducted abroad. This study is limited to the studies included in the analysis. This meta-analysis study, which has been conducted with very few studies, is thought to be a guide for further meta-analysis studies, especially on play therapy. In new 
studies to be done, studies that will examine the effectiveness of play therapy studies in a more comprehensive way will be useful. Studies to reveal in which areas play therapy is more effective may be proactive for researchers. Studies to determine the factors that limit and increase the effect of play therapy in new studies will contribute to researchers and experts working on play therapy. Including statistical data in the play therapy studies will result more comprehensive meta-analysis work and more reliable results.

\section{References}

Ahbab, A. (2019). Öfke Problemi Olan Çocuklarda Çocuk Merkezli Oyun Terapisinin Etkisi [The Effect Of Child-Centered Play Therapy On Children With Anger Problems]. Master Thesis. Uskudar University Institute of Social Sciences, Department of Clinical Pyschology. Istanbul.

Altun, K., Demir, V. \& Ünübol, H. (2019). The Effects of Developmental Play Therapy on Post-Traumatic Emotional Stress of 4-8 Years Old Children Living in Children's Homes. International journal of social sciences. 2(2), 35-46.

Arslan, A. \& Dilci, T. (2018). Investigation of the Effects of Children's Plays on Children's Development Fields in the Context of Past and Present (Sivas City Sample). Firat University Journal of Social Sciences. 28(1), 47-59.

AydınY eşilyurt, G. (2019). Child- Centered Play Therapy for Children with Specific Learning Disabilities; Its Effects on Perceived Parental Attitudes, Anxiety and Academic Achievement. Master Thesis. Maltepe University Institute of Social Sciences. Istanbul.

Bayam, A. (2017). Investigation of the Changes in Social Skills and Language Development Caused by Play Sessions for Children with Autism Spectrum Disorder Between 2-6 Years. Master Thesis. Beykent University Institute of Social Sciences Department of Pyschology Department of Clinical Psychology Department. Istanbul.

Blanco, P., Holliman, R., Ceballos, P., \&Farnam, J. (2019). Exploring the İmpact of ChildCentered Play Therapy on Academic Achievement of at-risk kindergarten students. International Journal of Play Therapy, 28 (3), s. 133-143.

Blanco, P.J. \& Ray, D.C. (2011). Play Therapy in Elementary Schools: A Best Practice for Improving Academic Achievement. Journal of Counseling \& Development, 89(2). DOI: 10.1002 / j.1556-6678.2011.tb00083.x

Bratton, S.C., Ray, D., Rhine, T. \&Jones,L (2006). The Efficacy of Play Therapy With Children: A Meta-Analytic Review of Treatment Outcomes. Professional Psychology: Research and Practice. 36(4), 376-390. DOI: 10.1037/0735-7028.36.4.376

British Association of Play Therapists (2020). A History of Play Therapy. https://www.bapt.info/play-therapy/history-play-therapy/ it was taken from the web site on 14.05.2020.

Chinekesh, A., Kamalian, M., Eltemasi, M. Chinekesh, S. \&Alavi, M. (2013). The Effect of Group Play Therapy on Social-Emotional Skills in Pre-School Children. Global Journal of Health Science, 6(2), 1916-9744.

Cohen, J. (1992). Statistical power analysis. Current Directions in Psychological Science, $1(3), 98-101$.

Deniz, E.A. (2019). Investigation of the Effect of Child-Centered Play Therapy on the Development of Social Skills in Children with Autism. Master Thesis. Necmettin Erbakan University, Institute of Educational Sciences, Department of Special Education. Konya.

Dinçer, S. (2014). Empirical meta-analysis in Educational sciences. Ankara: Pegem A. 
Sezen Dursun, Ş. (2018). Oyuna Genel Bakış [Play Overview]. (ed.Ekici, B.\&Yııldız Bıçakçı, M.). Bring Autism to the Game Neuroplay Method. Ekinoks Publ. 4th Edition.

Halmatov, S. (2018). Practical Techniques in Play Therapy. Ankara. Pegem Academy.

Gökcan, H.N. (2020) The Effect of Group Play Education Program on Social Satisfaction of Children Between 66-72 Months. Master Thesis. Akdeniz University. Institute of Education Sciences. Antalya.

Göçmen, G. (2004). A General Ecaluation of Meta-Analysis. Sakarya University Faculty of Education Journal. 0(7), 186-192.

Iswinarti, I. \& Hidayah, N. (2020). Empathy enhancement through group play therapy to reduce aggressive behavior. Jurnal Konseling dan Pendidikan. 8(3), 151-158 DOI: https://doi.org/10.29210/147900.

Hayati, M., Far, N.S., Nikroo, M. \& Faramarzi, E. (2014). Effectiveness of Child-Centered Play Therapy in the Decrease of Aggression among 5- To 10-Year-Old Children. International Journal of Psychology and Behavioral Research. 3(4), 308-316.

Kaduson, H.G. (2019). Travma Sonrası Stres Bozukluğu Olan Çocuklarla Serbest Bırakma Oyun Terapisi [Release Play Therapy with Children with Post-Traumatic Stress Disorder] (ed.Kaduson, H. G \& Schaefer, C. E., Trn. Öktem, F. \& KocatepeAvc1, U.). Short Term Play Therapy for Children. Nobel Publ. 3rd Edition. March. Ankara.

Karakoç, B. Eryılmaz, K., Özpolat, E.T. \&Yıldırım, İ. (2020). The Effect of Game Based Learning on Student Achievement: A Meta-Analysis Study. Knowledge and Learning, 27, 207-222.

Karsl1, E. (2016). Çocuk, Oyun ve Eğitim [Kids, Play and Education]. Meral Ören (ed). Children and Play.Page: 3-22. Eskişehir. Anadolu University Publ.

Keskin, A. (2009). The Effect of Games on The Development of Children's Multiple Intelligence Fields. Master Thesis. Selcuk University. Social Sciences Insititute. Konya.

Kılınç, F.E. \&Saltık, N. (2020). Investigation of the Effect of Play Therapy on Problem Behaviors of Children Living in Women's Shelters. ACU Journal of Health Sciences.11(1):27-34.

Kural, E. (2020). The Effect of Science Teaching Based on Multiple Intelligence Theory on Academic Achievement and Attitude Towards the Course: A Meta-Analysis Study. Master Thesis. Sivas Cumhuriyet University Institute of Educational Sciences Department of Primary Education. Sivas.

Koç Başaran, Y. (2017). Sampling Theory in Social Sciences. Journal of Academic Social Research, 5(47), 480-495.

Koç, Ş. \& Yumru, H. (2019). Use of Child Health Nursing Practice in Play Therapy in Turkey. Pediatric Practrice and Research, 7(4), 121-127.

Koçkaya, S. \& Siyez, D.M. (2017). The Effect of Play Therapy Applications on Preschool Children's Shyness Behavior. Current Approaches in Psychiatry, 9(1):31-44 doi:10.18863/pgy.281082

Lin, Y. \& Bratton, S.C (2015). A meta-analytic review of child- centered play therapy approaches. Journal of Counseling and Development, 93(1), 45-58. doi: 10.1002/j.1556-6676.2015.00180.x

LeBlanc M. \& Ritchie M. (2001). A meta-analysis of play therapy outcomes. Counselling Psychology Quarterly. 14 (2): 149-163.

Mantemayor, L. (2014) Exploring the effectiveness of child-centered play therapy in young children: a quantitative single case research design (Doctoral thesis). Texas, Texas A \& M University.

Öğretir, A.D. (2008). Play and Play Therapy] Gazi University. Journal of Industrial Arts Education Faculty. 22, 94-100. 
Önder, M. (2018). Contribution of Plays and Toys to Children's Value Education. Asian Journal of Education and Training, 4(2), 146-149, DOI: 10.20448/journal.522.2018.42.146.149.

Ray, D. C., Blanco, P. J., Sullivan, J. M., \& Holliman, R. (2009). An Exploratory Study of Child-Centered Play Therapy with Aggressive Children. International Journal of Play Therapy, 18(3), 162-175.

Ray, D.C, Armstrong, S.A, Balkin, R.S \& Jayne, K.M (2015). Child- centered play therapy in the schools: Review and meta analysis, Psychology in the Schools, 52(2), 107123. doi: 10.1002 / pits. 21798

Saltik, N. (2018). Investigation of the Effects of Play Therapy on Social Skills and Problem Behaviors in Children Living in Women's Shelters. Master Thesis. Ankara Y1ldirım Beyazit University Institute of Heath Sciences. Ankara.

Schottelkorb, A., Swan, K.L \& Ogawa, Y. (2020). Intensive Child-Centered Play Therapy for Children on the Autism Spectrum: A Pilot Study. Journal of Counseling\& Development, 98, 63-73.

Schumann, B. (2010). Effectiveness of child-centered play therapy for children referred for aggression. In J. N. Baggerly, D. C. Ray, \& S. C. Bratton (Eds.), Child-centered play therapy research: The evidence base for effective practice (p. 193-208). John Wiley \& Sons Inc.

Slade, M.K. \& Warne, R.T. (2016). A Meta-Analysis of The Effectiveness of TraumaFocused Cognitive-Behavioral Therapy And Play Therapy For Child Victims of Abuse. Journal of Young Investigators. 30(6), 36-43.

Sezici, E. (2013). The Effect of Play Therapy on Social Competence and Behavior Management in Preschool Children. Doctoral Thesis. Marmara University Institute of Health Sciences. Istanbul.

Soniya, S., Solomon, R. (2019). Effectiveness of Play Therapy on Anxiety among Hospitalized Preschool Children. Asian Journal of Nursing Education and Research. 9(2):193-196. [DOI:10.5958/2349-2996.2019.00040.5]

Sutton-Smith, B. (2008). To play or not to play. The Pennsylvania Newspaper, pp. 18-19, January-February.

Swan, K.L. \& Ray, D. (2014). Effects of Child-Centered Play Therapy on Irritability and Hyperactivity Behaviors of Children with Intellectual Disabilities. Journal of Humanistic Counseling. 53(2), 279-294.DOI: 10.1002/j.2161-1939.2014.00053.x

Şen, S. (2019). How to Make Meta-Analysis with SPSS?. Harran Education Journal, 4(1), 2149 http://dx.doi.org/10.22596/2019.0401.21.49

Thalheimer, W., \& Cook, S. (2002, August). How to calculate effect sizes from published research articles: A simplified methodology. Retrieved November 31, 2002 from http://work-learning.com/effect_sizes.htm.

Temizel, B. (2019) The Effect of Child-Centered Play Therapy on Anxiety Levels in Children Between 4-9 Years: A Retrospective Study] Master Thesis. Uskudar University Institute of Social Sciences. Department of Clinical Psychology. Istanbul.

Tuğrul. B. (2019). Oyunun Gücü [The Power of the Play]. Ayşe Belgin Aksoy (ed). Play in Preschool Education. Page: 12-32. Ankara. Hedef Publ.

TDK (2020) https://sozluk.gov.tr/ 09.05.2020 take on.

Uysal, R.B. (2020). The Effect of Theraplay Play Therapy on Emotional Problems and Behavior Problems on Syrian Refugee Children. Istanbul Bilgi University Graduate Programs Institute. Trauma and Disaster Studies Applied Mental Health Master Program. Istanbul.

VanFleet, R., Sywulak, A.S. \& Sniscak, C.C. (2020) Child-Centered Play Therapy (çev: Kural, H.U. \&Tuncel, B.) Apamer Psyychology Publ. 2nd Edition. Istanbul. 
Vanfleet, R. \& Faa-Thompson, T. (2010). The Case For Using Anımal Assisted Play Therapy. Bri. J. Play Therapy, 6, 4-18

Yaman, D. (2019). Teachers' Views on the Effect of Play on the Social Development of Children with Special Needs. Master's Thesis. Near East University. Instute of Educational Sciences. Department of Special Education. Cyprus.

Yavuzer, H. (2005). Çocuk psikolojisi [Child Psychology]. Remzi Publ. Istanbul.

Walsh, G., Sproule, L., McGuinness, C., Trew, K., Rafferty, H. \& Sheehy, N. (2006). An appropriate curriculum for 4-5- year-old children in Northern Ireland: Comparing play-based and formal approaches. Early Years, 26 (2), 201-221.

Wilson, K. \&Ryan,V. (2005). Play Threapy: A Non-Directive Approach for Children And Adolescents (2nd ed.). London: Balliere Tindall.

Whitebread, D., Basilio, M., Kuvalja, M. \& Verma, M. (2012). The Importance of Play: A report on the value of children's play with a series of policy recommendations. Written for Toy Industries of Europe (TIE), April 